logos_i_ethos_2014_2_(37), s. 203-216

DOI: http://dx.doi.org/10.15633/lie.803

Piotr S. Mazur

\title{
Mieczysława A. Krąpca koncepcja uniwersytetu
}

Trudno przecenić znaczenie nauki we współczesnym świecie. Ma ona przemożny wpływ na przemiany kulturalne i cywilizacyjne, ekonomiczne i gospodarcze, społeczne i polityczne. Nie ma takiej sfery życia ludzkiego i nie tylko, która nie zmieniłaby się pod jej wpływem. W panującym od oświecenia paradygmacie postępu nauka pełni rolę narzędzia przemiany rzeczywistości i udoskonalenia samego człowieka. $\mathrm{W}$ niej poszukuje się rozwiązania właściwie wszystkich ludzkich problemów, zapominając przy tym często, czemu - a właściwie komu - ma służyć. Na plan pierwszy wysuwa się praktyczny wymiar badań i forsowanie takiego modelu uprawiania nauki, który od wszystkich jej dziedzin, także humanistycznych, wymaga realizowania celów o charakterze instrumentalnym. Arystotelesowski model nauki scire propter scire został zdominowany przez model pozytywistyczny: scire propter uti, ukierunkowany na przetwarzanie istniejącej rzeczywistości ${ }^{1}$. Jest faktem, że model ten przynosi wymierne rezultaty w sferze praktycznej, ale i tu nie rozwiązuje wszystkich problemów,

Piotr Stanisław Mazur (Akademia Ignatianum w Krakowie) - profesor nadzwyczajny, kierownik Katedry Filozofii Człowieka w Akademii Ignatianum w Krakowie, członek Polskiego Towarzystwa Tomasza z Akwinu. Opublikował m.in.: Intelekt człowieka, Lublin 2004; W kręgu pytań o człowieka, Lublin 2008, Prowidencja ludzka jako podstawa roztropnego formowania zasad $\dot{z} y$ cia osobowego i społecznego człowieka, Kraków 2009; O polską kulturę humanistyczną, Lublin 2011; Spór o osobę w świetle klasycznej koncepcji człowieka. Studia i rozprawy [red.], Kraków 2012; Wokół genezy człowieka. Studia i rozprawy, [red.], Kraków 2013; Dynamizm - dynamizm ludzki - dynamizm osoby. Studia i rozprawy, [red.], Kraków 2014.

Stanisław Kamiński zwraca uwagę na skrajny instrumentalizm - poziom naukowości danej wiedzy wiąże ze stopniem jej użyteczności technicznej lub humanistycznej. Zob. S. Kamiński, Nauka i metoda. Pojęcie nauki i klasyfikacja nauk, Lublin 1998, s. 193. 
zwłaszcza problemów człowieka, bo nawet wówczas, kiedy jedne usuwa, rodzi następne. Pierwszym zaś problemem są liczne zagrożenia związane $\mathrm{z}$ instrumentalnym podejściem do człowieka.

Wskutek dominującego dziś modelu poznania naukowego coraz częściej cele nauki i cele samego człowieka są rozbieżne, zaś prymat przyznaje się tym pierwszym. Tymczasem nauka, która wyrosła ze zdziwienia człowieka wobec rzeczywistości, miała mu służyć w coraz pełniejszym poznaniu siebie i świata, a przez to jego doskonaleniu osobowemu. To właśnie w tym celu w okresie średniowiecza władze duchowne i świeckie tworzyły w Europie uniwersytety, nadając zgromadzonym w nich wspólnotom uczonych prawa gwarantujące niezależność ekonomiczną oraz wolność w dociekaniu prawdy w przekonaniu, że to ona najlepiej służy człowiekowi, nie zaś dla poszukiwania narzędzi manipulowania nim. W dyskusji z obowiązującym modelem uprawiania nauki i w odwołaniu do średniowiecznych korzeni uniwersytetu powstawała refleksja nad teoretycznymi zadaniami poznania naukowego oraz praktyczne realizowanie tego poznania, organizowanie jego warunków i zarządzanie jego formami, proponowane przez ojca profesora Mieczysława Alberta Krąpca, rektora Katolickiego Uniwersytetu Lubelskiego w latach 1970-1983. Choć zasadnicze wątki jego koncepcji uniwersytetu powstały w warunkach politycznego zniewolenia społeczeństwa i wszelkich instytucji społecznych, w tym także uniwersytetów, propozycja ta nie straciła niczego ze swej aktualności.

\section{Uniwersytet jako wspólnota}

Dzieje instytucji, jaką jest uniwersytet, liczą sobie kilkaset lat². Krąpiec podkreśla, że jest to dzieło kultury chrześcijańskiej średniowiecza. I w odwołaniu do tych inspiracji, które legły u źródeł średniowiecznych

2 Étienne Gilson podkreśla, że ustalenie chronologii w powstawaniu uniwersytetów jest niemożliwe. Część uniwersytetów wywodzi się ze szkół, które istniały już przed końcem XII wieku. Najstarszymi były uniwersytety w Bolonii, Paryżu, Oxfordzie i Orleanie. Dokładniejsze daty powstawania uniwersytetów można wskazać dopiero po roku 1200. Zob. E. Gilson, Historia filozofii chrześcijańskiej w wiekach średnich, tłum. S. Zalewski, Warszawa 1987, s. 227. 
uniwersytetów należy szukać jego własnej koncepcji. W universitas magistrorum et scholarium widzi on

zespół nauczających i ich słuchaczy biorących udział w określonym studium na określonym terenie ${ }^{3}$.

Definicję tę uzupełnia drugą, bardziej przedmiotową: stwierdzając, że z uniwersytetem wiąże się

wszechstronne metodyczne uprawianie wiedzy naukowej i jej przekazywanie na poziomie najwyższym w danej epoce kulturowej ${ }^{4}$.

Rozwijając pierwsze określenie, należy podkreślić, że uniwersytet to wspólnota ludzi „oddanych nauce” - universitas collegiorum et scientiarum $^{5}$. Społeczność uniwersytecka zgromadzona w wyodrębnionym spośród innych miejscu do prowadzenia badań naukowych jest zarazem dobrowolna i różnorodna. Buduje ją podejmowany wspólnie wysiłek w celu poznania prawdy, co sprzyja wszechstronnemu rozwojowi intelektualnemu (spotkanie przedstawicieli różnych dyscyplin), jak i nawiązywaniu relacji interpersonalnych. W tym znaczeniu uniwersytet jest przede wszystkim miejscem spotkania ludzi reprezentujących różne dziedziny poznania, uczonych i ich uczniów, także różne narodowości i stany społeczne, którzy tworzą „wyodrębnioną społeczność - civitas academica. Podstawą jej organizowania jest podejmowanie wspólnego wysiłku, jakim jest zdobywanie wiedzy. W realizacji tego celu konieczne jest jednak respektowanie pluralizmu w poszukiwaniu prawdy i budowanie relacji międzyludzkich na personalistycznych podstawach. Stąd, zdaniem Krąpca, tworząc średniowieczną universitas, jej członkowie uczyli się „poszanowania dla różnych dys-

M. A. Krąpiec, Uniwersytet, [w:] Powszechna encyklopedia filozofii, t. 9, red. nauk. A. Maryniarczyk, Lublin 2008, s. 605.

Tamże.

M. A. Krąpiec, Człowiek, kultura, uniwersytet, Lublin 1998, s. 330. 


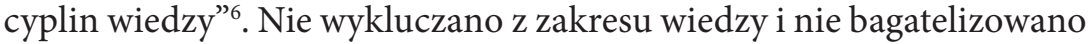
żadnej nauki. Uczono się poszanowania praw i zwyczajów mniejszych kolegiów i wydziałów, demokracji i sprawowania rządów w społeczności ludzi wolnych. Naukę uprawiali ludzie wolni, w sposób wolny, podległy jedynie wymogom prawdy i poprawności metodologicznej jej poznawania. Wolność była, jest i pozostanie zasadą życia uniwersyteckiego, zarówno w uprawianiu nauki, jak i życiu członków społeczności akademickiej. Sposób uprawiania nauki i życia uniwersyteckiego wytwarzał w ludziach przynależnych do wspólnoty uniwersyteckiej „uniwersalistyczną mentalność”, dla której charakterystyczne były: personalistyczne rozumiany humanizm i demokracja. Te właśnie elementy stanowiły o moralnym znaczeniu uniwersytetu. Stawał się on wzorem życia społecznego dla innych zrzeszeń. Obraz uniwersytetu zarysowany przez Krąpca należałoby tu jeszcze dopełnić w kontekście modnych dziś koncepcji tolerancji i multikulturalizmu. Przede wszystkim średniowiecza universitas, mimo wszystkich zróżnicowań - narodowych i kulturowych, powstawała na jednym wspólnym fundamencie cywilizacyjnym. Tworzenie wspólnoty $\mathrm{z}$ innymi osobami oraz szacunek dla człowieka i dla odmienności jego poglądów w żaden sposób nie znosił wymogów, jakie niesie ze sobą dążenie do poznania i głoszenia prawdy. „Uniwersalistyczną mentalność, o jakiej mówi Krąpiec, uzyskuje się poprzez wieloaspektowe poznanie prawdy i w ukierunkowaniu na prawdę, nigdy zaś poza czy ponad nią.

Dla Krąpca podkreślenie wspólnotowego wymiaru uniwersytetu jest istotne jeszcze z jednego względu. Chodzi o przekraczanie ograniczeń związanych z niedoskonałością ludzkiego poznania i jego aspektowością. Z jednej strony konieczna jest ścisła specjalizacja w badaniach naukowych, co prowadzi do ogromnej partykularyzacji wiedzy ludzkiej i w pewnym sensie do atomizacji poszczególnych dyscyplin, z drugiej zaś istnieje potrzeba ciągłej nad nią refleksji, nieustanego jej scalania i poszukiwania syntezy poprzez wskazywanie zasadniczego celu wiedzy i przyporządkowanie tej wiedzy dobru człowieka także 
po to, aby nie zatraciła ona swojego sensu. Utylitarne podejście do nauki sprawia, że niektóre typy wiedzy uznaje się za wartościowsze od innych. Naukom praktycznym przyznaje się współcześnie wyraźny prymat przed naukami teoretycznymi. Przekształcanie rzeczywistości i samego człowieka stawia się dziś często ponad ich poznaniem. Zarazem poznanie naukowe oderwane od swoich humanistycznych korzeni dehumanizuje się, sprzyjając ujmowaniu człowieka w zdepersonalizowany sposób.

\section{Prawda jako cel organizowania wspólnoty}

Zarówno w przeszłości, jak i współcześnie wspólnota uniwersytecka organizuje się wokół i w celu poznania prawdy. Wszystkie inne powody tworzenia wspólnoty uniwersyteckiej mają w niej swoje źródło, zakorzenienie i sens, bez którego pozbawione są racji bytu. Jeśli więc uniwersytet ma być uniwersytetem, to cała tworząca go wspólnota musi być uorganizowana wokół prawdy: jej nieustannego poszukiwania, pogłębiania, a w tych aspektach, w których jest już ujęta - obrony. Prawdę trzeba przy tym rozumieć analogicznie. $W$ ujęciu metafizycznym, na które stale wskazuje Krąpiec, prawda to sam byt, a świat jest mnogością bytów, stąd poznanie ludzkie zorganizowane w uniwersytetach winno zmierzać do ogarnięcia całej rzeczywistości. Poznanie tej rzeczywistości stanowi dla nauki wyzwanie także dlatego, że nawet ujęcia aspektów koniecznościowych rzeczy, które odsłania filozofia, a konkretniej metafizyka, domaga się ciągłego pogłębiania i doprecyzowywania. W tym sensie nie ma takiej dziedziny poznania, która byłaby poznawczo zamknięta. To poszukiwanie prawdy w badaniach naukowych prowadzonych w uniwersytecie jest nie tylko zadaniem poznawczym, ale ma też dla Krąpca wymiar normatywny, związany społecznym do niej dochodzeniem:

Społeczny wymiar uprawiania nauki to wspólne poszukiwanie prawdy przez profesorów, asystentów i studentów, to zbiorowe podejmowanie doniosłych, długofalowych tematów badawczych, a „zbiorowe” potrzebne jest dla wzajemnej kontroli 
postępowania badawczego i osiągniętych wyników, ale może jeszcze bardziej - by główny cel nauki, jakim jest osiągnięcie prawdy, nie umknął z pola widzenia naukowców, by prawdy nie przysłoniły wartości utylitarne, polityczne i tym podobne, by rangę osiągnięć naukowych wyznaczały kryteria poznawcze ${ }^{7}$.

Uniwersytet wyrósł z przekonania, że pełnię prawdy zdobywa się we wspólnocie poprzez korzystanie z dorobku poznawczego osób drugich, wzajemną inspirację i konfrontację polegającą na ukazywaniu ograniczeń i błędów oraz poprzez doskonalenie stosowanych metod i narzędzi służących do jej poznania. Ten wspólnotowy wymiar prawdy zdobywanej wspólnym wysiłkiem ludzi nauki sprawia, że nie jest ona własnością jednostki. Poznana prawda, zwłaszcza zaś prawda o człowieku, jest dobrem dla całej universitas i dla każdego członka tej społeczności, służąc jako podstawa dalszych poszukiwań i osobowego doskonalenia.

Prawda, jakkolwiek nie zawsze klarowna, przebijająca się przez różnorodność poglądów, stanowisk, jest rdzeniem życia uniwersyteckiego, które bez niej łatwo redukuje się do wspólnoty towarzyskiej, grupy interesów czy narzędzia indoktrynacji. A ponieważ poznanie jest fundamentem całego życia osobowego człowieka i wszystkich jego aktywności kulturowych, to uniwersytet jest powołany do jej pielęgnowania także poprzez jej głoszenie i przekazywanie. I dlatego uniwersytet jest wspólnotą uczonych i tych, którzy dopiero do tego miana aspirują. Praca naukowa musi łączyć się z wysiłkiem dydaktycznym, którego celem jest wprowadzenie uczących się w już zdobytą wiedzę i wyposażenie ich w narzędzia konieczne do dalszego poznania. Obok właściwie kształtowanych relacji międzyosobowych, istotnym aspektem wspólnotowego zdobywania prawdy w społeczności akademickiej jest upodmiotowienie a zarazem wzajemna współpraca poszczególnych jednostek uniwersytetu (wydziałów). Wspólnotowość i prawda w życiu uniwersyteckim nieustannie się ze sobą przeplatają i uzupełniają. Poprzez swoje oddanie prawdzie wspólnota uniwersytecka służy samemu człowiekowi: 
[p]ielęgnując prawdę społeczność naukowa strzeże zarazem wartości personalistycznych. Człowiek może być bowiem suwerenną osobą tylko wówczas, gdy jest w posiadaniu prawdy ${ }^{8}$.

Poznanie prawdy i nauczanie prawdy w warunkach uniwersytetu wymaga zdaniem Krąpca wolności. Ta zaś może się zrealizować dzięki zapewnieniu uniwersytetowi potrójnej otwartości: od wewnątrz, od zewnątrz i „otwartości na prawdę”. Pierwsza dotyczy samej koncepcji nauki i naukowości, która wymaga wyjścia poza ograniczenia jej współczesnego modelu. Chodzi o poszerzenie zakresu poznania (przedmiotowo i podmiotowo) oraz wyraźniejsze ujęcie celu jego działania. Tym zaś jest położenie większego nacisku na poznanie człowieka, a nie tylko na realizację celów instrumentalnych. Z tym właśnie związana jest potrzeba otwartości na pełną prawdę o świecie i człowieku. Chodzi o to, by nauka mogła też pełnić funkcję czysto poznawczą, niezdeterminowaną wprost przez cele instrumentalne i tym samym, aby mogła być nakierowana na życie osobowe człowieka. Potrzeba także autonomii uniwersytetu „od zewnątrz” w postaci pluralizmu kulturowego, wolności badań, publikacji i dialogu, respektowania podstawowych wymogów metodologicznych i odmienności poszczególnych dziedzin nauki.

\section{Człowiek jako główny przedmiot poznania}

Krąpiec ma świadomość, że przedmiotem poznania ludzkiego, także tego realizowanego w uniwersytetach, jest cała rzeczywistość. Różnorodność dyscyplin naukowych wskazuje na to, że nie ma takiego aspektu rzeczywistości, który nie byłby przedmiotem ludzkiego zainteresowania poznawczego. Nie oznacza to jednak, że wszystkie problemy są równie ważne, o czym świadczy obowiązujący dziś paradygmat poznania naukowego, który na pierwszym miejscu stawia zagadnienia praktyczne i domaga się ich rozwiązywania. Na bok usuwa się natomiast

Tamże.

Tamże, s. 289. 
fundamentalne pytania o człowieka, o jego naturę, funkcjonowanie czy sens istnienia. $\mathrm{W}$ rezultacie poznanie naukowe zostaje $\mathrm{w}$ znaczący sposób zawężone, zinstrumentalizowane i oderwane od swojego zasadniczego celu. Poznanie ludzkie jest podstawą wszystkich aktywności kulturowych człowieka, a kultura przyporządkowana jest do jego dobra osobowego. I dlatego rdzeniem badań naukowych i ogniskową życia uniwersyteckiego winno być w przekonaniu Krąpca poszukiwanie prawdy o człowieku:

[...] [C]złowiek spełnia się jako człowiek w swoich aktach osobowo-poznawczych, w swych decyzjach, w swej miłości do człowieka drugiego, aniżeli w swym stosunku do rzeczy, do narzędzi, które wytwarza i udoskonala. Zatem, czyż poznanie człowieka $\mathrm{w}$ jego bytowej strukturze, $\mathrm{w}$ jego istotnie ludzkiej działalności, decyzji, miłości, komunikowaniu się z drugim człowiekiem nie powinno przede wszystkim stanowić przedmiotu dociekań studiów uniwersyteckich? I to tym bardziej, że pierwotnie uniwersytety średniowieczne prawie bez reszty były poświęcone problematyce specyficznie ludzkiej, humanistycznej ${ }^{10}$.

W perspektywie człowieka, ujmowanego tu jako przedmiotowy zwornik poznania naukowego można dokonać uporządkowania i zrozumienia sensu uprawiania poszczególnych dyscyplin. Tylko w jego świetle nie są one przypadkowym zbiorem zatomizowanych dyscyplin ograniczonych do swoich partykularnych celów poznawczych, lecz głęboko racjonalną próbą poznawczej odpowiedzi człowieka na rzeczywistość, w której on sam dany jest sobie jako tajemnica. Zaproponowany przez Krąpca sposób spojrzenia na uniwersytet jako wspólnotę uczonych skupionych wokół poznania prawdy o człowieku ma fundamentalne znaczenie dla zrozumienia roli zwłaszcza kierunków humanistycznych, którym bardzo często odmawia się dziś prawa do odgrywania równorzędnej roli w stosunku do nauk przyrodniczych czy technicznych, i to na różnych poziomach. Wiąże się to z pomniejszaniem społecznego znaczenia tego typu poznania i kształcenia, co znajduje także 
wyraz w polityce nauki prowadzonej zarówno wewnątrz, jak i na zewnątrz uniwersytetów.

Miejsce nauk humanistycznych i schemat organizacji uniwersytetu zwięźle ujął Krąpiec w jednym ze swoich wystąpień, kiedy pełnił funkcję rektora KUL:

W naszej pracy badawczej i dydaktycznej [...] mamy na warsztacie sprawy stanowiące rdzeń kultury humanistycznej, chrześcijańskiej, polskiej. To wszystko, co istotnie dotyczy człowieka, zwłaszcza zaś jego strony osobowej, stanowiło i stanowi przedmiot naszych rozlicznych zabiegów poznawczych. Poznanie człowieka w jego strukturze bytowej, w kontekście życia społecznego, w wytworach jego ducha, a nade wszystko w jego odwiecznym przeznaczeniu - stanowi bowiem zasadniczą osnowę pracy naszych Wydziałów ${ }^{11}$.

I dodaje:

Właśnie dziś - jak nigdy przedtem w historii - trzeba odzyskać człowieka dla niego samego ${ }^{12}$.

Tak oto wyłania się racjonalna struktura zogniskowanego na człowieku poznania naukowego. Jeśli badania prowadzone w uniwersytetach skupiają się na człowieku, to właściwie wszystkie dziedziny w swojej różnorodności winny być przepojone refleksją filozoficzną i teologiczną, a zarazem każda dziedzina ma do spełnienia swoją rolę w tym poznaniu. Teologia $\mathrm{w}$ aspekcie zbawienia podejmuje problemy związane z ostatecznym sensem ludzkiego istnienia, zasadami ludzkiego działania, ustosunkowaniem się do zła, cierpienia czy śmierci. Jak podkreśla Krąpiec, właśnie za sprawą teologii wiele zagadnień weszło do kultury europejskiej: wolność osobista, związek miłości i odpowiedzialności, autonomia nauki itd. ${ }^{13}$. Uprawianie teologii wymaga odwołania do

\footnotetext{
11 Tamże, s. 308.

12 Tamże.

13 Tamże, s. 284.
} 
filozofii, która dostarcza teologii narzędzi poznawczych i tworzy płaszczyznę dialogu na temat człowieka na poziomie poznania naturalnego. Zasadniczym jednak celem poznania filozoficznego jest podejmowanie podstawowych problemów dotyczących samego człowieka, jego osobowego statusu, jego natury, jego wyjątkowego miejsca pośród istniejących bytów. W badaniach tych należy odwołać się do filozofii klasycznej oraz uwzględniać nowe rozwiązania i współczesny dorobek metodologiczny. Filozofia klasyczna jest przy tym nieodzowna, z uwagi na poznanie bytu ludzkiego w aspekcie ogólnoegzystencjalnym, ukazującym jego ontyczne, koniecznościowe i ostatecznościowe racje, oraz z uwagi na jej odwołanie w poznaniu do języka naturalnego, który jest ,jedynym łącznikiem myśli i bytu" ${ }^{\prime 4}$. Natomiast nauki społeczne i humanistyczne dążą do ujęcia warunków i prawidłowości ludzkiego funkcjonowania i działania, a także do poznania go w świetle jego wytworów intencjonalnych. Zdaniem Krąpca sens uprawiania tych dyscyplin nie wynika tylko z racji przedmiotowych, ale i podmiotowych, gdyż człowiek

[...] nie chce ograniczyć się do poznawania dyrektyw przekształcania przyrody i społeczeństwa, lecz pragnie poznać te rejony, które są pozornie nieużyteczne, a które jednak nadają wartość ludzkiemu życiu ${ }^{15}$.

Człowiek zmierza bowiem do aktualizacji swojej osobowej natury przez poznanie prawdy, realizowanie dobra i akty decyzyjne, tworzenie piękna, a także przez nawiązywanie osobowej relacji z Absolutem. Studia uniwersyteckie winny obejmować wszystkie te dziedziny ludzkiej kultury. We współczesnych warunkach zadanie takiego poznania

14 Tamże. Zaproponowane przez Krąpca rozumienie roli filozofii w życiu uniwersyteckim zwięźle charakteryzuje A. Wawrzyniak: „Filozofowi uniwersytetu nie może być obojętna ranga obecności samej filozofii w życiu akademickim, jej rola w spełnianiu przez uniwersytet funkcji kulturalnych i społecznych. Przywrócenie filozofii rangi fundamentu i zarazem zwornika gmachu wiedzy uniwersyteckiej i wykształcenia akademickiego wiąże się, zdaniem Autora [M. A. Krąpca - przypis P. S. Mazur], z powrotem do wielkiej, klasycznej filozofii uniwersalnej, porządkującej całościowo obraz świata i przynoszącej ustaloną przez wieki prawdę o człowieku” (A. Wawrzyniak, Od redaktora wydania I, w: M. A. Krąpiec, Człowiek, kultura, uniwersytet, s. 8).

15 Tamże, s. 284. 
i kształtowania człowieka spoczywa zaś zwłaszcza na uniwersytetach katolickich, które powstawały po to, by łączyć wiedzę z wiarą ${ }^{16}$.

\section{Wyzwania współczesności i przyszłość uniwersytetu}

Współczesny model poznania naukowego oparty na pytaniu jak? i ukierunkowany na tworzenie narzędzi do przekształcania przyrody i życia społecznego uznaje Krąpiec za fakt. Zarzuca mu jednak zbyt wąską koncepcję poznania, dalece niewystarczającą wobec pytań o charakterze egzystencjalnym i uniwersalistycznym, które stawia sobie człowiek $^{17}$. Zdecydowanie bliższe ludzkim oczekiwaniom jest klasyczne pytanie dia ti (dzięki czemu). Podejście to jest wyrazem ogólniejszego przekonania, że poznanie naukowe nie powinno ignorować pytan formułowanych przez człowieka $\mathrm{w}$ perspektywie poznania potocznego, z którego w czasach starożytnych nauka wyrosła ${ }^{18}$.

Znaczenie nauki dla realizacji celów gospodarczych, politycznych, kulturowych czy cywilizacyjnych wymaga ponownego przemyślenia $\mathrm{w}$ aspekcie podmiotowym i przedmiotowym oraz uporządkowania celów i środków samej nauki. W sytuacji, gdy mimo ogromu wiedzy człowiek jest wciąż dla siebie zagadką, do jego poznania wezwana jest zwłaszcza filozofia, ale nie tylko ona. Konieczne jest także dopełnienie pozostałych dziedzin poznania właśnie prawdą o człowieku, aby właściwie ujmować relację pomiędzy środkami, którymi są warunki materialne i narzędzia działania, a samym człowiekiem jako ich podmiotem i ostatecznym celem. Potrzeba zmiany współczesnego podejścia do nauki obejmuje nie tylko kształtowanie odpowiedniej polityki nauki na

16 Zob. M. A. Krąpiec, Uniwersytet, s. 607.

17 „Struktura rzeczywistości, sens ludzkiego życia i pracy postuluje znacznie szerszą koncepcję nauki aniżeli ta, która uformowała się zasadniczo w XIX w. i była mocno związana z wytwarzaniem coraz doskonalszych narzędzi, a przez to z cywilizacją konsumpcyjną, której tamte problemy nie interesują" (M. A. Krąpiec, Człowiek, kultura, uniwersytet, s. 285).

$18 \mathrm{Na}$ temat spontanicznych pytań człowieka pod adresem rzeczywistości zob. M. A. Krąpiec, Filozofia co wyjaśnia? Rozumieć rzeczywistość świata i człowieka, Warszawa 1997, s. $17-65$. 
zewnątrz uniwersytetów, ale także - zgodnie z postulatami Krąpca - humanizacji samej nauki, humanizacji także w znaczeniu odpowiedzialności za poznanie prawdy o człowieku, jej głoszenie i jej obecność w życiu publicznym. Humanizacja ta musi objąć wszystkie dziedziny poznania, od filozofii poczynając, a kończąc na dziedzinach praktycznych. Wiele z prowadzonych dziś badań zagraża bowiem wprost życiu czy integralności bytowej człowieka. Samej zaś filozofii, która wraz z teologią stanowić ma zrąb poznania naukowego, nie są obce błędy poznawcze w rozumieniu człowieka, deformacje w pojmowaniu ludzkiej wolności czy forsowanie naturalizmu "naukowego"19.

Aktualność koncepcji uniwersytetu proponowanej przez Krąpca rysuje się na tle coraz większych współczesnych zagrożeń dla uprawiania nauki, do których w Polsce należą różnego typu bariery ograniczające wolność uniwersytetów, pogłębiające się trudności o charakterze ekonomicznym czy potężny niż demograficzny zmuszający szkoły wyższe do poszukiwania modnych wśród ludzi młodych, ale niekoniecznie ważnych dla kultury czy gospodarki kierunków studiów czy badań. Na działalność uczelni wyższych, jak i samych naukowców w coraz większym stopniu oddziałują wymogi biurokratyczne. Istnieje też stała presja uzyskiwania wymiernych, praktycznych rezultatów badań i nauczania, jeśli nie we wszystkich, to możliwie w jak największej liczbie dyscyplin naukowych. Wiąże się to z pomniejszaniem znaczenia nauk nieinstrumentalnych, pełniących jednak ważną (kulturotwórczą) rolę w rozwoju kultury narodowej. Z rysujących się przed nauką i uniwersytetem zagrożeń zdawał sobie Krąpiec doskonale sprawę i wielokrotnie na różne sposoby dawał wyraz trosce o jej stan. Był przecież człowiekiem do ostatnich chwil swojego życia oddanym nauce i pracującym w środowisku uniwersyteckim. Niezależnie jednak od diametralnie zmieniających się warunków, w jakich przychodzi funkcjonować uniwersytetom, są one jego zdaniem wezwane do pełnienia wciąż tej samej, z niczym nieporównywalnej i niczym niezastępowalnej, funkcji kulturowej: 
Uniwersytet jest organizmem żywym, który ciągle musi poszukiwać i bronić swej tożsamości w zmieniających się warunkach historycznych. Będąc społecznością osób o wyraźnych profilach, osób „nieduplikatów”, jest środowiskiem równie ciekawym, co niełatwym. Kierowanie takim zespołem jest możliwe jedynie przy powszechnym - spontanicznym lub zreflektowanym - uznaniu wspólnej płaszczyzny, wspólnego celu i pobytu na uniwersytecie. Jest nim społeczne dochodzenie do prawdy, jako podstawa działalności naukowej i poczynań kulturowych ${ }^{20}$.

Uniwersalna idea uniwersytetu jako „społecznego dochodzenia do prawdy" musi w określonych warunkach kulturowych znaleźć swoją konkretyzację. Przed światem nauki stoi w każdym czasie zadanie poszukiwania swoistego modus vivendi w relacjach ze światem kultury, polityki czy gospodarki, w tym konieczność uświadamiania społecznego znaczenia poznania prawdy jako służby człowiekowi.

\section{Zakończenie}

Uniwersytet w wizji Krąpca ma spełniać nie tylko rolę poznawczą, ale i wychowawczą. To miejsce ciągłej i wytężonej pracy intelektualnej, ukierunkowanej na poznanie prawdy oraz miejsce spotkania $z$ drugim człowiekiem. Twórcza wymiana poglądów łączy się tu z wzajemnym kształtowaniem swojego poznania oraz pełnym od strony osobowej dojrzewaniem do wieczności ${ }^{21}$. Człowiek przygotowuje się bowiem do niej w warunkach życia społecznego poprzez kulturę, a uniwersytet jest tym miejscem, gdzie tworzy się fundamenty kultury, gdzie stosownie do swojego osobowego statusu rozumnie poznaje się rzeczywistość

20 Tenże, Człowiek, kultura, uniwersytet, s. 350, (wyróżnienie tekstu - P. S. M).

${ }^{21}$ „Studia uniwersyteckie prowadziły badania nad człowiekiem jako bytem suwerennym i nad środkami umożliwiającymi racjonalne ludzkie działanie. Człowiek jako osoba jest w realnym świecie kimś, kto jest dla siebie celem jako stworzony przez Boga, na obraz i podobieństwo Boga, i jako taki spełnienie swojego życia osiąga jedynie w Bogu. Dlatego trzeba poznać strukturę bytową człowieka, jego rozumne działanie, jego wolność i jej granice. Takie poznanie domaga się zorganizowanych studiów" (M. A. Krąpiec, Uniwersytet, s. 607). 
i odpowiedzialnie podejmuje się w niej działanie, zwłaszcza wobec drugiego człowieka. Konieczne jest zatem ciągłe zwracanie uwagi na społeczny, wspólnotowy wymiar działalności uniwersyteckiej i na poznanie prawdy, które jest zarówno przywilejem, jak i zadaniem ludzi zawodowo uprawiających naukę. Etos poznania naukowego kształtujący się w uniwersytetach musi łączyć się z dążeniem do doskonalenia moralnego, do integrowania przez samego człowieka porządku swojego poznania świata i porządku działania. W tym kontekście konieczne jest pojmowanie poznania prawdy jako służby człowiekowi podejmowanej duchu miłości i odpowiedzialności, przez co zarazem najpełniej uwyraźnia się specyfika genus humanum:

Tradycyjne ukonstytuowany uniwersytet buduje kulturę humanistyczną jako podstawowe środowisko, w którym osoba ludzka może spełnić podstawowy postulat starożytnej paidei - poznanie siebie [gnoti seautón] ${ }^{22}$.

\section{Bibliografia}

Gilson É., Historia filozofii chrześcijańskiej w wiekach średnich, tłum. S. Zalewski, Warszawa 1987.

Kamiński S., Nauka i metoda. Pojęcie nauki i klasyfikacja nauk, Lublin 1998.

Krąpiec M. A., Człowiek jako osoba, Lublin 2005.

Krąpiec M. A., Człowiek kultura uniwersytet, Lublin 1998.

Krąpiec M. A., Filozofia co wyjaśnia? Rozumieć rzeczywistość świata i człowieka, Warszawa 1997.

Krąpiec M. A., Uniwersytet, [w:] Powszechna encyklopedia filozofii, t. 9, red. nauk. A. Maryniarczyk, Lublin 2008.

O uniwersytecie, red. A. Maryniarczyk, T. Duma, K. Stępień, Lublin 2014, (Wykłady Otwarte imienia Ojca Profesora Mieczysława A. Krąpca OP). 